\title{
GLOTTALIZATION, PREASPIRATION AND GEMINATION IN ENGLISH AND SCANDINAVIAN
}

\author{
by Frederik Kortlandt — Leiden
}

Docherty et alii have "noted that several sociolinguistic accounts have shown a sharp distinction between the social trajectories for glottal replacement as opposed to glottal reinforcement, which have normally been treated by phonologists as aspects of 'the same thing'. It may therefore not always be appropriate to treat the two phenomena as manifestations of a single process or as points on a single continuum (presumably along which speakers move through time). From the speaker's point of view (as manifested by different patterns of speaker behaviour) they appear as independent phenomena" (1997: 307). In particular, "while the glottal stop is spreading rapidly in mainstream English, glottal reinforcement (especially of $/ \mathrm{p} /$ and $/ \mathrm{k} /$ in intervocalic positions) is possibly recessive. It is characteristic not only of Tyneside male speech but also of rather conservative rural varieties, such as those of south-west Scotland and much of Northern Ireland" (o.c.: 306). This supports my view that the "reinforcing" glottal closure of ['p], ['t], ['k] is ancient, in spite of the recent spread of the replacing glottal stop in mainstream English (cf. Kortlandt 1997b).

The two types of glottal variant are clearly distinct in Newcastle English, where they moreover exhibit quite different sociolinguistic patterns. The replacing glottal stop "is variably substituted for noninitial pre-vocalic/t/ (e.g. in set off, water) by younger speakers, especially middle-class females, and as such appears to be a non-local form entering Newcastle English" whereas the preglottalized variants "by contrast, are largely the preserve of older males" (Docherty \& Foulkes 1999: 54). It appears that the preglottalized stops "differ from the 'pure' glottal variants in terms of the presence of movement of the second formant in the previous vowel: formant transitions are caused by gestures involving the supralaryngeal vocal organs. $79 \%$ of our tokens contained F2 transitions, the exceptional cases sounding clearly like glottal stops" (o.c.: 57). It turns out that "older males appear to be producing glottalised tokens with a different articulatory co-ordination than other members of the speech community: they have a greater tendency to time the oral gesture such that it lags behind the accompanying glottal articulation" (o.c.: 61f.). Thus, preglottalization is disappearing from the language while the 
replacing glottal stop is spreading in the speech of the younger generation.

While the "increasing space given by phoneticians from about 1920 onwards to the treatment of the glottal stop" (Andrésen 1968: 34) can be explained by the phonemic character of the glottal replacement, the earlier preglottalization of $/ \mathrm{p} /, / \mathrm{t} /, / \mathrm{k} /$ went unnoticed because it was not distinctive. Glottalization is pervasive in pre-1930 audio recordings of people born in the second half of the $19^{\text {th }}$ century, even in formal delivery (cf. Kortlandt 1997b, with ref.). It follows that glottalization was well-established in upper-class English speech in the $19^{\text {th }}$ century and must have been widespread in the standard language of that time. The lack of attention to this phenomenon can be explained not only by the subphonemic character of preglottalization but also by its loss in pre-pausal position. While "glottal variants are widespread in various phonological contexts in Newcastle, they are almost categorically prohibited in pre-pausal position. Tokens before a pause are instead - from an auditory perspective - clearly 'released' voiceless alveolars" (Docherty \& Foulkes 1999: 62). It appears that either the glottalization or the buccal features could be lost in prepausal position: "In Derby glottal stops in pre-pausal position are far more widespread, but in the self-conscious context of word-list readings most speakers produce what sound like 'released' [t]s, just as in Newcastle" (1.c.). This suggests that pre-pausal [t] is due to restoration and that the spread of the replacing glottal stop in mainstream English may have started from pre-pausal positions.

This brings the original distribution of the English glottalization closer to its Danish counterpart, the so-called vestjysk stød, which is found immediately before the plosives $p, t, k$ "wherever these stand in an original medial position, following a voiced sound in a stressed syllable" (Ringgaard 1960: 195). The vestjysk stød cannot possibly be connected with the Jylland apocope because it is also found in the northeastern part of the vestfynsk dialects, where the apocope did not take place. The vestjysk stød in these isolated dialects suggests that it is a retention rather than an innovation. Moreover, Hansson has drawn attention to the fact that vestjysk stød is found on original monosyllables and polysyllables alike in the most remote and isolated villages on the island of Als, where it coexists with true pitch accents representing the original accents 1 and 2 from which the Common Danish stød opposition developed (2001: 166). We must conclude that outside these archaic dialects the vestjysk stød was lost in monosyllables, as was the case with preglottalization in Newcastle English. 
The preglottalized stops of English and Danish cannot be separated from the preaspirated stops in the northern Scandinavian languages. The geographical distribution of preaspiration has recently been examined in detail by Hansson (2001: 158-164), who concludes that it is a peripheral archaism to be identified historically with the vestjysk stød. Hansson points out that we find preaspiration proper in Icelandic, Faroese, the Norwegian dialects of Jæren, North Gudbrandsdal, most of Härjedalen, and the island of Senja, the Swedish dialects of northeastern Uppland (Gräsö, Valö, Hållnäs, Forsmark), of the Åland island of Kökar and some nearby dialects, the Estonian Swedish dialect of Ormsö, the Lapland dialects of Vilhelmina and Arjeplog (where it may be attributed to Saami influence), and in a spoken corpus from Central Standard Swedish. Most importantly, preaspiration is found not only in original geminates and in stops before sonorants, as in Icelandic, but also in single $/ \mathrm{p} /, / \mathrm{t} /, / \mathrm{k} /$ between vowels and word-finally after a vowel, especially in Faroese (cf. already Kortlandt 2000: 61) and in the dialects of Uppland (Gräsö). We find extensive sonorant devoicing before $/ \mathrm{p} /, / \mathrm{t} /, / \mathrm{k} /$ in the same areas as preaspiration proper while devoicing of $/ 1 /$ and especially $/ \mathrm{r} /$ is more widespread, covering most of the Norwegian and Swedish territory. The strong geographical correlation between preaspiration proper and extensive sonorant devoicing and the much wider distribution of the devoicing of $/ \mathrm{r} /$ and /1/ suggest that preaspiration was lost after a vowel in the larger part of Scandinavia.

We now turn to the origin of the Scandinavian preaspiration. Hansson assumes that $/ \mathrm{p} /, / \mathrm{t} /, / \mathrm{k} /$ were "phonetically preaspirated in all non-initial positions in Late Proto-Scandinavian" (2001: 167) but takes an agnostic position on the ultimate origins of preaspiration, proposing that $/ \mathrm{p} /, / \mathrm{t} /, / \mathrm{k} /$ "became either preaspirated or preglottalized through a simple sound change", viz. "a slight misalignment of articulatory gestures", and assuming that "preglottalization developed out of preaspiration" without adducing any arguments for this assumption (o.c.: 169). He thinks that preaspiration was phonemicized in Icelandic as a result of devoicing of voiced stops (o.c.: 168) but suggests in a footnote that it may have resulted from the shortening of long vowels in closed syllables if $/ \mathrm{b} /, / \mathrm{d} /, / \mathrm{g} /$ were already voiceless at the time. The latter view comes close to my own. In fact, there is no evidence for voiced obstruents in Proto-Scandinavian because the voiceless stops of e.g. Icelandic henda 'throw', vagga 'cradle', bera 'carry' (o.c.: 164) may go all the way back to Proto-Germanic. Indeed, the "hardening" of voiced fricatives to voiceless stops 
(ibidem) suggests that the fricatives were actually voiceless at that time. Elsewhere I have proposed that intervocalic $*-d-$ became a fricative between the earlier and the later syncope (1988: 4) and that all obstruents were voiceless in North-West Germanic (1996: 54). I think that the rise of phonemic voicedness was a more recent development which took place under Romance and subsequently Low German influence and eventually led to the loss of preaspiration in South and Central Scandinavian.

The close correspondence between preglottalization in English and Danish suggests that preaspiration developed out of it in the northern Scandinavian languages. I am inclined to identify the development with the fricativization of postvocalic $* d[\mathrm{t}]$ between the earlier and the later syncope, which can be dated to the $7^{\text {th }}$ century. The loss of glottal constriction in the preglottalized stops yielded preaspiration in the same way as the loss of occlusion in postvocalic $b[\mathrm{p}], d[\mathrm{t}], g[\mathrm{k}]$ yielded fricatives. This account of the facts offers parallel explanations for the Scandinavian preaspiration and the High German consonant shift, where the new affricates [pf], [ts], [kx] can be derived from preglottalized stops ['p], ['t], ['k] by loss of the buccal occlusion with concomitant oralization (klusilspring) of the glottal constriction (cf. Kortlandt 1997a). Thus, I think that OHG. helpfan, English hel'p, Vestjysk hjoel'b and Icelandic hjálhpa all developed from ProtoGermanic *hel'p- and that conservative English dialects have best preserved the original sound structure.

The reconstruction of preglottalized stops sheds new light on the quantity shift in Scandinavian because the phonetic difference between preglottalized and geminated stops is slight, the glottal constriction preceding the buccal closure in the former but not in the latter instance. As a result, preglottalization could easily be reanalyzed as gemination, entailing the rise of new closed syllables. This mechanism accounts in a principled way for the existence of several layers of gemination in North and West Germanic (cf. Kortlandt 1988: 7). It also explains the fact "that in Härjedalen, only the more innovative dialects (as opposed to that of Vemdal) preaspirate these secondary geminates, and on Kökar, only younger speakers preaspirate them. Both are obvious cases of later generalization" (Hansson 2001: 172, note 3), similar to the generalization of sonorant devoicing before /s/ in Faroese (o.c.: 162f.). While preaspiration was lost after lengthened short vowels before single stops in most of the West and North Norwegian, Faroese and Icelandic dialects, the lengthening was evidently anticipated by the rise of geminates from preglottalized stops in East Norwegian and 
Central and North Swedish dialects, except after the low vowels $a$ and $a$, which were lengthened (cf. Perridon 2002: 73), e.g. Swedish vecka 'week', droppe 'drop', skepp 'ship', but äta 'eat', cf. ON. vika, dropi, skip, OE. wice, dropa, scip. As in the case of preaspiration in Härjedalen and Kökar and sonorant devoicing in Faroese, gemination could be generalized by lengthening $/ \mathrm{s} /$ and $/ \mathrm{m} /$ after short vowels, and even other resonants in the Norwegian dialect of Bergen (o.c.: 76).

Elsewhere I have argued that the preglottalization which I have reconstructed for Proto-Germanic can be identified with the preglottalization which must be reconstructed for other Indo-European languages on the basis of direct evidence from Baltic and Indic and indirect evidence from Indo-Iranian, Greek, Latin and Slavic (see especially Kortlandt 1985). Hansson's view that this hypothesis "hinges on the validity of the Glottalic Theory as such" (2001: 169) is mistaken because my reconstruction of Proto-Germanic preglottalization is based on its actual attestation in English and western Danish and on the derivation of preaspiration in northern Scandinavian, of various layers of gemination in North and West Germanic, and of affrication in High German (and English dialects) from natural developments of the same, irrespective of its origins. Perridon asks rhetorically: "If for instance the geminated fricative in High German essen is the reflex of a preglottalized stop in Pgerm., why then is there in this case no preaspiration in Icelandic, no (vestjysk) stød in the western dialects of Danish, no glottal stop in English, nor gemination in Central and North Swedish?" (2002: 74, note 3). The answer in simple: preaspiration was lost after a lengthened short vowel in Icelandic (but not in northern Faroese), preglottalization was usually lost in monosyllables in vestjysk and English (but preserved in polysyllabic forms of such words), and gemination did not arise after lengthened $a, c$ in Central and North Swedish (as Perridon remarks himself, o.c.: 73). Note that preaspiration is actually attested in Faroese eta [e:hta] (Kortlandt 2000: 61) and preglottalization in Old Northumbrian eatta (Kortlandt 1997b: 177), where the double consonant cannot denote either a preceding short vowel (because the attested form is earlier than the lengthening of short vowels in northern English) or a true geminate (because the short vowel is regularly lengthened at a later stage in these dialects). The hitherto unexplained double consonants in the Lindisfarne Gospels and Rushworth glosses are another phenomenon which is accounted for by the reconstruction of preglottalized stops for Proto-Germanic (cf. ibidem). 


\section{References}

Andrésen, Bjørn Stålhane. 1968. Pre-glottalization in English standard pronunciation. Oslo.

Docherty, Gerard J., Paul Foulkes, James Milroy, Lesley Milroy \& David Walshaw. 1997. Descriptive adequacy in phonology: a variationist perspective. Journal of Linguistics 33, 275-310.

Docherty, Gerard J., \& Paul Foulkes. 1999. Derby and Newcastle: instrumental phonetics and variationist studies. Urban voices: accent studies in the British Isles (edited by Paul Foulkes \& Gerard Docherty) London, 47-71.

Hansson, Gunnar Ólafur. 2001. Remains of a submerged continent: preaspiration in the languages of Northwest Europe. Historical Linguistics 1999 (edited by Laurel J. Brinton) Amsterdam, 157-173.

Kortlandt, Frederik. 1985. Proto-Indo-European glottalic stops: the comparative evidence. Folia Linguistica Historica 6/2, 183-201.

-. 1988. Proto-Germanic obstruents. $A B \ddot{a} G$ 27, 3-10.

—. 1996. The High German consonant shift. $A B \ddot{a} G$ 46, 53-57.

—. 1997a. Korrektur. $A B \ddot{a} G$ 47, 231.

-. 1997b. How old is the English glottal stop? NOWELE 31-32 [Fs. Liberman], 175-179.

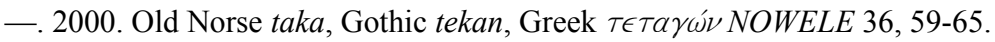

Perridon, Harry. 2002. The quantity shift in North Germanic. ABäG 56, 69-77.

Ringgaard, Kristian. 1960. Vestjysk stød. Aarhus. 